\title{
Proposal for a 2007 Caddo Archaeology Summit Meeting
}

Timothy K. Perttula

Heritage Research Center, Stephen F. Austin State University

Follow this and additional works at: https://scholarworks.sfasu.edu/ita

Part of the American Material Culture Commons, Archaeological Anthropology Commons, Environmental Studies Commons, Other American Studies Commons, Other Arts and Humanities Commons, Other History of Art, Architecture, and Archaeology Commons, and the United States History Commons

Tell us how this article helped you.

This Article is brought to you for free and open access by the Center for Regional Heritage Research at SFA ScholarWorks. It has been accepted for inclusion in Index of Texas Archaeology: Open Access Gray Literature from the Lone Star State by an authorized editor of SFA ScholarWorks. For more information, please contact cdsscholarworks@sfasu.edu. 


\section{Proposal for a 2007 Caddo Archaeology Summit Meeting}

Creative Commons License

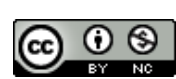

This work is licensed under a Creative Commons Attribution-NonCommercial 4.0 International License 


\title{
PROPOSAL FOR A 2007 CADDO ARCHAEOLOGY SUMMIT MEETING
}

\author{
Timothy K. Perttula
}

Archeological \& Environmental Consultants, LLC

The Caddo Indian peoples lived in parts of the four states of Arkansas (specifically southwest Arkansas), Louisiana (the northwestern part of the state), Oklahoma (the eastern region), and Texas (all of East Texas) from deep in prehistoric times until the early 1840s. They left behind an extensive archaeological record marked by important mound centers where the social and political elite lived and led community-wide rituals, ceremonies, and traditions; villages, hamlets, and farmsteads where the people carried out their daily lives; numerous cemeteries and burial grounds where the people were laid to rest following long-standing religious burial ceremonies; as well as salt-making sites, stone tool quarries, hunting camps, and other evidence of the Caddo people's use of the land long before Americans settled the region.

Archaeological research on the Caddo peoples is currently booming, mainly because of increased federal, state, and private development projects across the four-state region in recent years. New and significant information is being obtained every day on the archaeological heritage of the Caddo Indian peoples. Archaeologists in the Caddo area are also beginning to be more actively involved in working together with the modern descendants of the prehistoric Caddo peoples - the Caddo Nation of Oklahoma-to understand and document their rich native history.

All these developments are exciting, and serve as testimony to the fact that Caddo archaeology is alive and well. However, this excitement and promise must be tempered by the fact that the Caddo archaeological area is large, there are few archaeologists working in the Caddo area that specialize in the study of Caddo archaeology, and much of the current knowledge about the archaeological heritage of the Caddo peoples is not widely shared or understood within the archaeological community or by the broader and interested public in the four-state region.

Caddo archaeologists and the Caddo Nation of Oklahoma have been working together for some years on archaeological and cultural heritage issues of mutual interest. This has occurred principally through the annual Caddo Conference (which has been meeting on and off since the 1940s), the development of one-on-one working relationships between archaeologists and Caddo peoples, and through occasional jointly attended symposia, such as the 2005 Caddo History and Culture Symposium held at the Caddo Nation's tribal complex in Binger, Oklahoma.

No venue currently exists, however, where practicing Caddo archaeologists, and members of the Caddo Nation of Oklahoma, can actively share information and perspectives on new and past archaeological findings in the way it is envisioned by some Caddo archaeologists (myself included) is now necessary to improve and strengthen our understanding of Caddo culture. The time is right_-given the burgeoning archaeological data base and the past history of successful communication between the Caddo peoples and archaeologists—for the 
full development of a partnership of Caddo archaeologists and the Caddo Nation of Oklahoma. That partnership should be one where we can work together to innovatively study current research issues, themes, or topics that transcend a single site or region (i.e., such as the prehistoric origins of the Caddo peoples or the development and adoption of agriculture by the Caddo, to mention just a few research issues), but are basic to a broader and more compelling understanding of the cultural heritage of the Caddo Indian peoples. Working towards a new understanding of the prehistoric and early historic archaeology of the Caddo peoples demands a new synthesis of the archaeological record, based on knowledge gained from archaeological research, information from historical documents and maps, and the practices and memories of living Caddo members, especially tribal elders. New syntheses of archaeological findings will advance the field of Caddo archaeology and can also provide new information and products (i.e., books, websites, exhibits for local museums, tourism brochures, development of heritage trails, etc.) for those members of the general public interested in the heritage of the four-state region. Such new syntheses will also be important in identifying needs and priorities for future research which will benefit archaeologists, the Caddo Nation, and state and federal agencies responsible for the management of the region's archaeological heritage.

With this proposal, efforts are underway seeking funding to support the convening of a 4 day summit meeting in 2007 of Caddo archaeologists (perhaps four archaeologists from each state, or some other combination of 16 archaeologists) actively working in the four-state region and members of the Caddo Nation of Oklahoma (staff of the Historic Preservation Department and the Heritage Museum, and interested members of the Tribal Council and tribal elders). The purpose of the meeting would be three-fold: (1) to discuss the development of a partnership of Caddo archaeologists and the Caddo Nation of Oklahoma that can enhance the professional and public understanding of the cultural heritage of the Caddo peoples; (2) to discuss and reach consensus on how we can go about achieving a better and broader understanding on current and future research and heritage management issues and topics pertinent to each part of the Caddo archaeological area; and (3) to propose specific ways we can bring this better and broader understanding before the professional and avocational archaeological community as well as the general public.

Although meeting details have not been finalized, it will be important that the meeting should be held in a centrally-placed facility within the four-state Caddo archaeological region, relatively accessible to all participants. The summit meeting could be led by $2-3$ organizers who also would be participating in the summit.

\section{TENTATIVE AGENDA OF THE SUMMIT MEETING}

The proposed Caddo archaeology summit meeting would take place over four days and cover a considerable amount of ground in terms of discussions on archaeological research issues along with a vision for the future (i.e., a five year plan for research in the Caddo area, if you will); publication needs and opportunities; data base and management priorities and logistics; and other endeavors. If anyone reading this article has specific comments on the scope and direction of the proposed Caddo archaeology summit meeting — or would like to participate in the summit—please do not hesitate to contact the author. 


\section{The tentative agenda is as follows:}

Day 1: (a) Setting the Stage for why the Summit is needed; (b) Discussing the Partnership between Caddo archaeologists and the Caddo Nation of Oklahoma; and (c) Identifying current research issues and themes and heritage management/planning concerns.

Days 2 and 3: Break-out Sessions to: (a) discuss current and future research issues and topics pertinent to each part of the Caddo archaeological area, as well as shared strategies to pursue productive research directions; (b) discuss the content and preparation of a guiding document on needs and priorities for future research on Caddo archaeology; and (c) a general discussion on the development and use of modern technologies that can enhance archaeological understanding and facilitate broad syntheses and access to key information, such as sharing existing data bases of archaeological information (i.e., radiocarbon data bases, whole vessel data bases, etc.) and the development of a Caddo cyberinfrastructure (cf. Snow et al. 2006), sharing GIS layers of archaeological information, and the general use and sharing of remote sensing technologies.

Day 4, Summary of the Summit Meeting: (a) discuss the findings, proposals/strategies, and research agendas from the Day 2 and 3 Break-out-Sessions; (b) general discussion of how we can and will develop informative and synthetic products/resources for the archaeological community and the general public; and (c) ending with a consideration of future summit meetings and where does Caddo archaeology go from here.

Stay tuned for further news on the Caddo archaeology summit meeting.

\section{ACKNOWLEDGEMENTS}

I appreciate the comments received by Ann M. Early, George Sabo III, Robert Cast, and Gregory Vogel on the Caddo archaeology summit meeting proposal.

\section{REFERENCES CITED}

Snow, D. R., K. G. Hirth, and G. R. Milner

2006 Envisioning an Archaeological Cyberinfrastructure. The SAA Archaeological Record 6(5):15-16. 
